\title{
Synthesis of silver nano-particles using micro-emulsion technique
}

\author{
- Nguyen Phuoc Trung Hoa \\ - Pham Thuy Bich Tuyen \\ - Lam Quang Vinh \\ - Le Van Hieu \\ University of Science, VNU-HCM \\ (Manuscript received on March $20^{\text {th }} 2013$, accepted on January $14^{\text {th }} 2014$ )
}

\begin{abstract}
Silver nanoparticles were synthesized by mixing two micro-emulsion systems - one with precursor $\left(\mathrm{AgNO}_{3}\right)$ and one with reducing agent $\left(\mathrm{NaBH}_{4}\right)$. Dioctyl sodium sulfonsuccinate - AOT was used as surfactant. We studied parameters as $\omega-$ molar ratio of water to surfactant, hydrocarbon (oil) types. The molar ratio of water to surfactant was changed from 2.5 to 5; 7.5 and 10. The used oil types were cyclohexane, iso-octane, and dodecane.
\end{abstract}

$X R D, U V$-Vis and TEM images were used to elucidate the structure and size of the products. The results showed that, synthesized silver nanoparticles sizes were between $5-7 \mathrm{~nm}$, with homogeneously spherical shapes. The silver colloids were used in antibacterial applications. The antibacterial efficiency was very high, above $99 \%$ at $\sim 4 \mu \mathrm{g} / \mathrm{ml}$ concentration of silver nanoparticles.

Keywords: Silver nanoparticles, homogeneous shape, micro-emulsion.

\section{INTRODUCTION}

Silver nanoparticles have extensive applications in electronics [1, 2], optoelectronics [3], catalytic chemistry [4], and especially biomedicine $[5,6]$. The excellent anti-bacterial properties of silver nanoparticles can hardly be found in any other materials. This makes silver one of the most studied and researched materials.

There are many methods for synthesizing silver nanoparticles such as chemical reduction [7], photo reduction [8], laser ablation [9], gamma radiation [10], etc. Most of these methods are to produce the nanoparticles of a few ten nanometers in diameter and with broad size spectra.
Recently, micro-emulsion technique has been more and more exploited to synthesize highly mono-dispersed and small-sized nanoparticles in the world. Still, to our knowledge, there is very limited research in Vietnam about silver nanoparticles synthesis in micro-emulsion system.

In this technique, we can versatilely control the size and shape of the nano-products but do not need to put a large amount of stabilizer after synthesis. Not only spherical nanoparticles but also dendrite, nanowire, and hexagonal nanostructures [11] can be synthesized. 
A micro-emulsion system for metal nanoparticles synthesis consists of a continuous oil phase, a homogeneously dispersed aqueous phase which contains the reactants, and the surfactant. The reactants in the water pool are protected by the surfactants forming micells.
These micells may be considered as micro reactors for nanoparticles synthesis. When two or more micells come into contact with each other, they transfer their contents and the reactions happen.

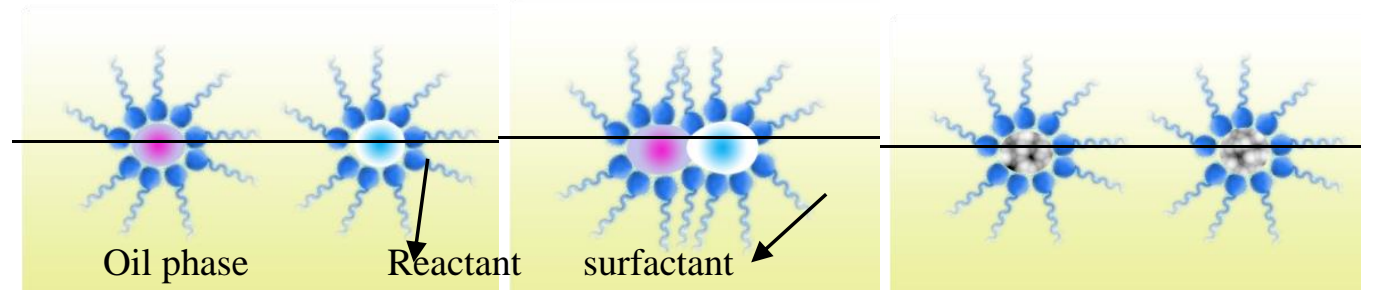

Fig. 1. Two micells (a) exchange their contents (b) and the reactions happen forming nanoparticles (c)

In this work, we studied the effect of $\omega$ molar ratio of water to surfactant, the types of continuous oil phase on the size of the synthesized nanoparticles and on the stability of the colloidal solutions.

\section{MATERIALS AND METHODS}

\section{Materials}

Double-distilled water, silver nitrate $(99.8 \%$, Guangdong Guanghua Ltd - China) as the precursor, dioctyl sodium sulfonsuccinate - AOT (96\%, Sigma Aldrich - USA) as the surfactant, sodium borohydride (92\%, Kanto Chemicals Japan) as the reducting agent, n-dodecane (95\%, Merck), isooctane, cyclohexane $(99.5 \%$, Guangdong Guanghua Ltd - China) as the dispersing media. All chemicals were used as received without further purification.

\section{Experimental process}

All the experiments were carried out at room temperature. First we prepared the two $0.1 \mathrm{M}$ solutions of silver nitrate and soldium borohydride. The soldium borohydride solution was prepared and used for only one experiment. We let AOT dissolve in cyclohexane with the assistance of weak magnetic agitation. The concentration of AOT in the solution was $0.2 \mathrm{M}$. The $\mathrm{AgNO}_{3}$ and $\mathrm{NaBH}_{4}$ solutions were then put into AOT/cyclohexane to form two stable microemulsions. After that, we let drop by drop of $\mathrm{AgNO}_{3}$ emulsion into $\mathrm{NaBH}_{4}$ emulsion. The final solution was magnetically mixed for two hours. The rotation speed of the magnetic bar was 500 rpm.

Trang 76 


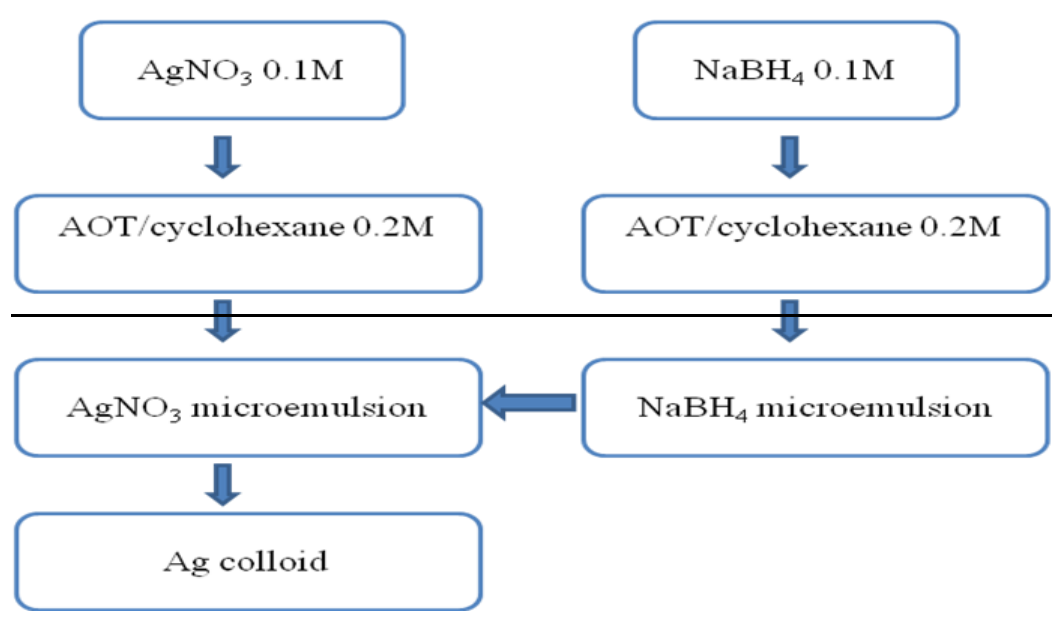

Fig. 2. Experimental process for silver nanoparticle synthesis in colloidal solution

The reduction of silver ion was shown in the equation:

$\mathrm{AgNO}_{3}+\mathrm{NaBH}_{4} \rightarrow \mathrm{Ag}+1 / 2 \mathrm{H}_{2}+1 / 2 \mathrm{~B}_{2} \mathrm{H}_{6}$ $+\mathrm{NaNO}_{3}$

To study the effect of $\omega-$ molar ratio of water to surfactant, we changed the value of $\omega$ from 2.5 to $5,7.5$ and 10 and used cyclohexane as the continuous oil phase.

To study the effect of oil types, we fixed $\omega=$ 5 and alternately used cyclohexane, isooctane and dodecane as the continuous oil phase.

\section{Characterization}

The synthesized colloidal solutions and nanoparticles were characterised by studying the XRD Spectra (D8 Advance, Bruker -Germany),
UV-Vis Spectra (Halo RB-10, Dynamica), and TEM Image (JEOL JEM 1400). To prepare for XRD, we centrifuged the sample at $5000 \mathrm{rpm}$ for 30 minutes. The pellet was obtained for XRD analysis. The anti-bacterial efficiency of the synthesized colloidal solutions was determined by Colony Count Test Method. The bacteria used in the test were E. coli ATCC 25922.

\section{RESULTS AND DISCUSSION}

\section{Effect of $\omega$}

As we mixed the two micro-emulsion systems, we observed that the solution color changed with time, from light yellow to yellow and then dark yellow, pale brown and dark brown. 


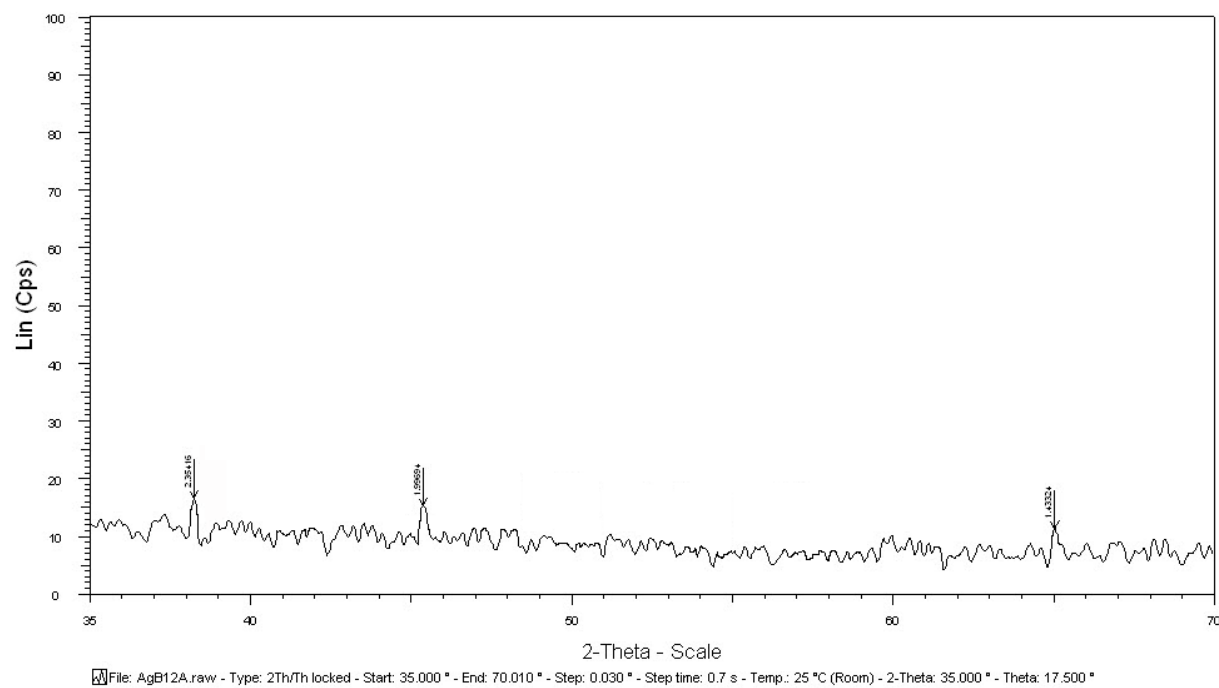

Fig. 3. XRD pattern of the synthesized silver nanoparticles

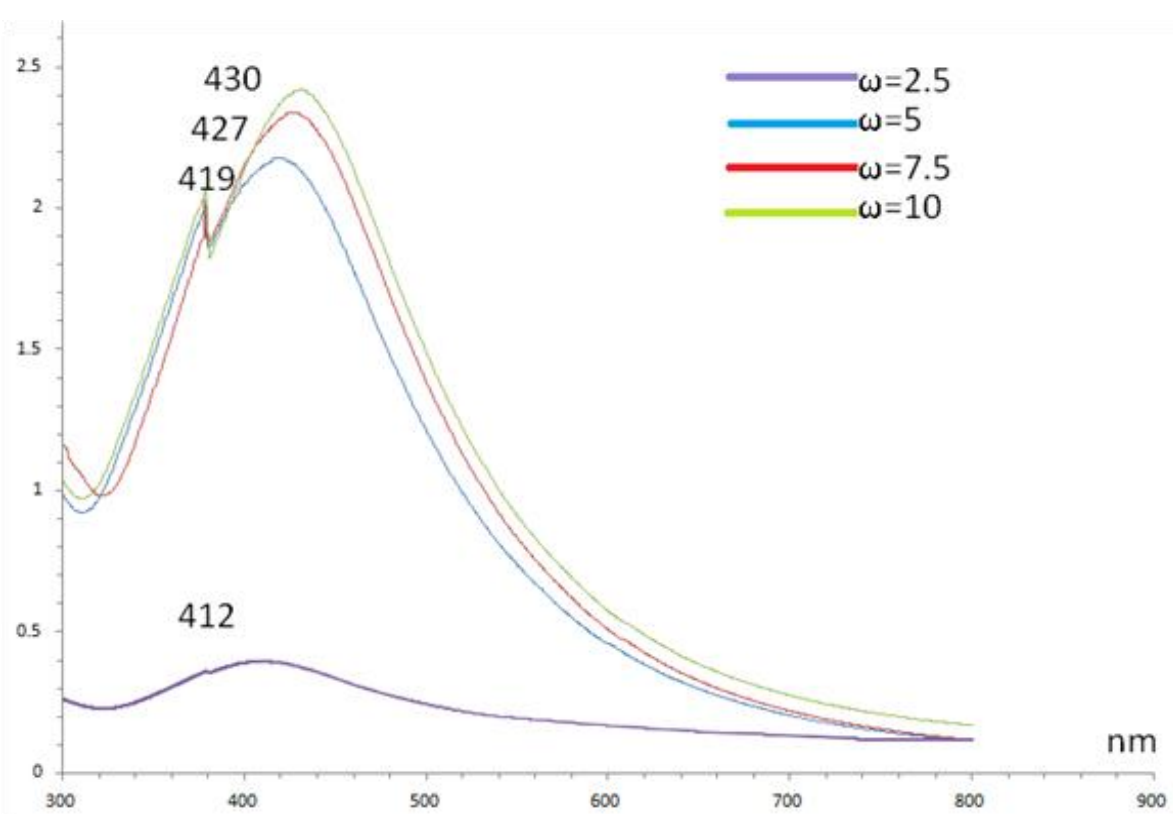

Fig. 4. UV-Vis absorption spectra of the synthesized colloids

The XRD pattern confirmed the existence of silver nanoparticles in the solution. We saw three significant peaks of silver corresponding to the diffraction planes (111), (200) and (220).

With $\omega=2.5$, the color change was slower than with other $\omega$ values $(5,7.5,10)$. That means the reactions happened slower and fewer nanoparticles were formed with $\omega=2.5$. An explanation for this is that AOT protected micells in the system by forming layers around micells. The more AOT molecules added, the better the micells were protected. This trend continued up to $\omega=10$.

\section{Trang 78}


Fig. 4 shows the UV-Vis absorption spectra of the colloidal solutions. With all the values of $\mathrm{w}$, there were absorption peaks between $412 \mathrm{~nm}$ and 430nm. The wavelength of the absorption peak increased as $\omega$ increased. For spherical nanoparticles, the red shift in UV-Vis spectra indicates that the sizes of the nanoparticles are larger [12]. Once again, we see the role of AOT molecules in protecting micells. With fewer AOT molecules, the micells interacted and exchanged their contents more easily. As a consequence, the nanoparticles had more growth time and get larger.

About the stability of the synthesized colloid, we left them in a dark room and at room temperature for several weeks and observed if there was any significant precipitate formed at the bottom of the bottle. Table 1 shows the stability of the synthesized colloids.

Table 1. Stability of the colloids with different values of molar ratio of water and surfactant

\begin{tabular}{|c|c|}
\hline$\omega$ & Stability \\
\hline 2.5 & Several months \\
\hline 5 & $>1$ months \\
\hline 7.5 & $>1$ months \\
\hline 10 & 3 weeks \\
\hline
\end{tabular}

\section{Effect of the oil types}

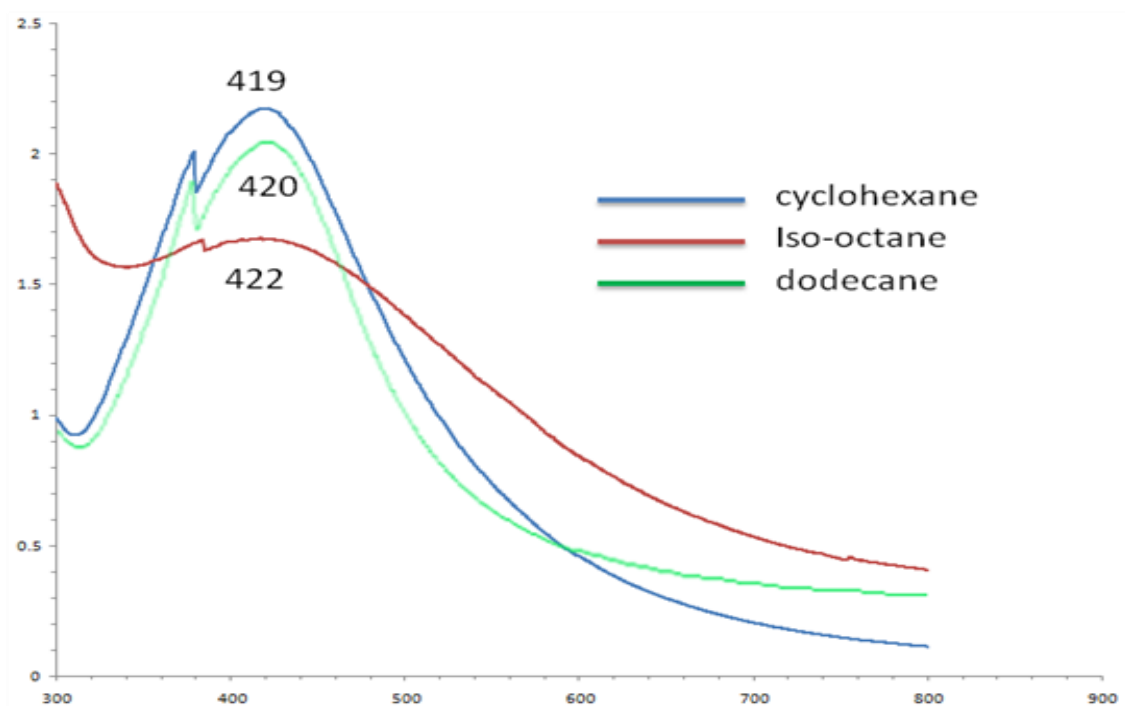

Fig. 5. UV-Vis absorption spectra of the colloids synthesized with cyclohexane, isooctane and dodecane

Fig. 5 shows that we successfully synthesized silver nanoparticles in all three solutions. The absorption peaks were at $422 \mathrm{~nm}$, $419 \mathrm{~nm}, 420 \mathrm{~nm}$ corresponding to the colloids synthesized in iso-octane, cyclohexane, dodecane. Although the peaks in spectra were different among the three colloids, we could not conclude about their correlations with the nanoparticle sizes because the peak depended also on the surrounding medium.

To determine the size of the synthesized nanoparticles, we analysed the TEM images. 


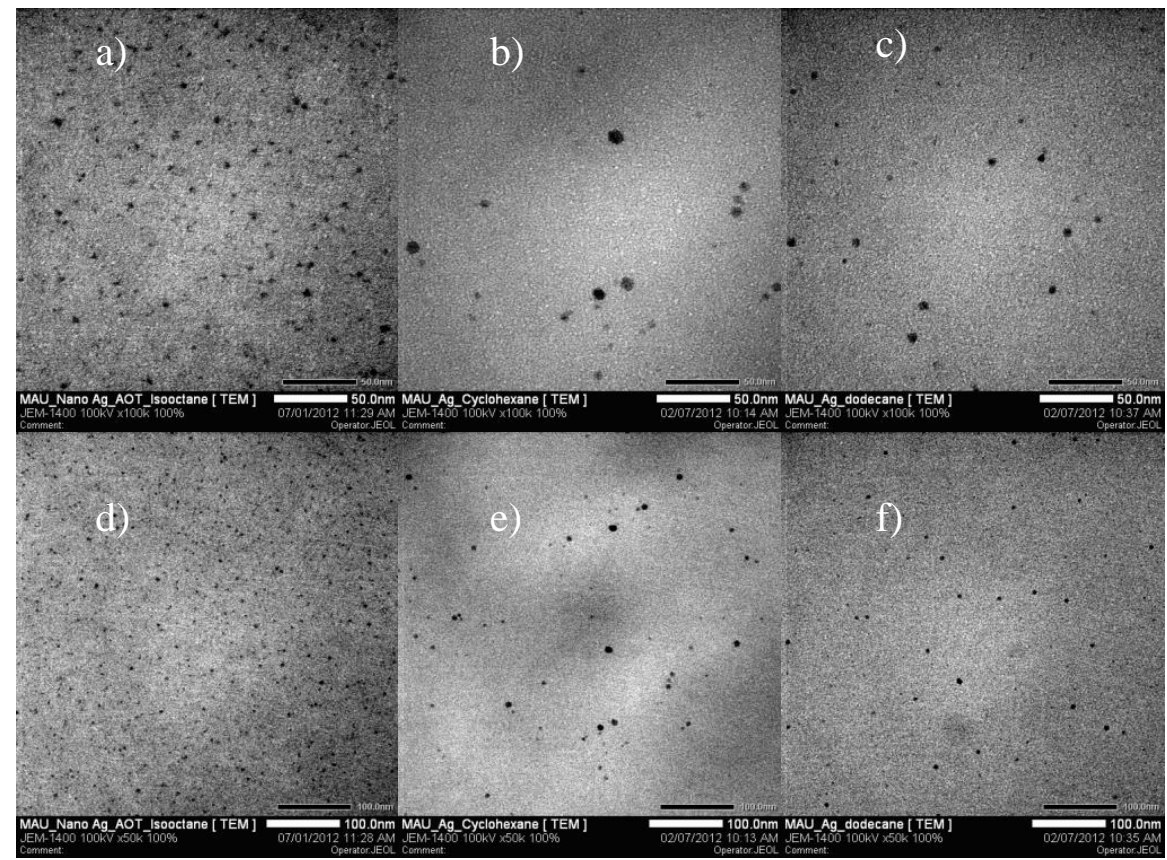

Fig. 5. TEM images of silver colloids synthesis in isooctane $(\mathrm{a}, \mathrm{d})$ cyclohexane $(\mathrm{b}, \mathrm{e})$ dodecane $(\mathrm{c}, \mathrm{f})$

As we can see in Fig. 5, with isooctane as oil phase, the synthesized nanoparticles are smaller and the density is higher in comparison with that of cyclohexane and dodecane.

Isooctane has the smallest value of viscosity among the three hydrocarbons: $0.51 \mathrm{mPas}$ (isooctane) comparing to $1.02 \mathrm{mPas}$ (cyclohexane) and $1.34 \mathrm{mPas}$ (dodecane).

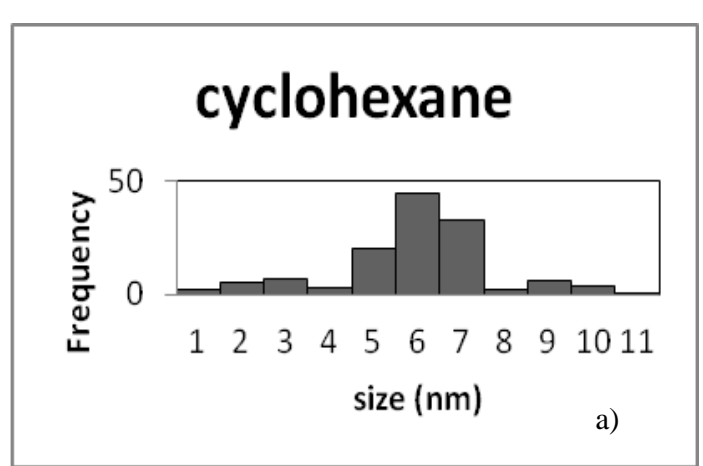

\section{Trang 80}
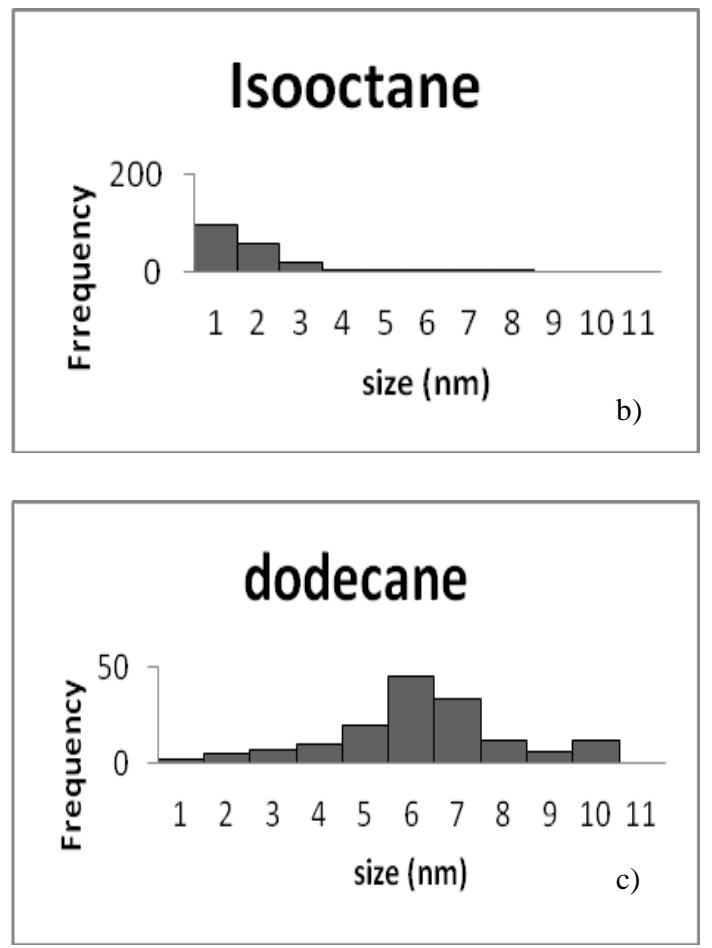

Fig. 6. Size distribution of silver nanoparticles in a/ cyclohexane $\mathrm{b} /$ isooctane $\mathrm{c} /$ dodecane 
So, micells in the isooctane solution had a higher exchange rate and correspondingly shorter exchange time. In such conditions, more silver atoms were formed, more nucleation sites were formed, but the nanoparticles were smaller because there was less time for them to grow.

To find out the distribution of nanoparticle size, we used the software ImageJ [13] to analyse the TEM images. The average sizes of nanoparticles in cyclohexane, iso-octane, dodecane correspondingly were $5.8 \pm 2.1,1.5 \pm$ $1.2,5.6 \pm 2.4$.

We could also predict the stability of the synthesized colloids. High collision rate of nanoparticles in isooctane would make them agglomerate more easily. And the colloid would be less stable than the other two.

Table 2. Stability of the colloids synthesized in different solutions

\begin{tabular}{|l|c|c|}
\hline Solution & Nanoparticles & Stability \\
\hline Iso-octane & $1.5 \pm 1.2$ & 3 weeks \\
\hline Cyclohexane & $5.8 \pm 2.1$ & $>1$ \\
\hline Dodecane & $5.6 \pm 2.4$ & $>4$ \\
\hline
\end{tabular}

Our result shows that dodecane is an excellent solution for silver nanoparticle synthesis. The colloidal solution could be stored for months without precipitation. We compared the TEM images of the colloid before and after 4 months, they showed that sizes and shapes of the nanoparticles did not change significantly.

To explain the very high stability of dodecane colloids, we took a look at the structure of dodecane. It's a highly viscous hydrocarbon with long carbon chains. These long chains make the molecules more coiled and have less interaction with the AOT molecules. In this condition, the AOT molecules provide better protection for the micells.
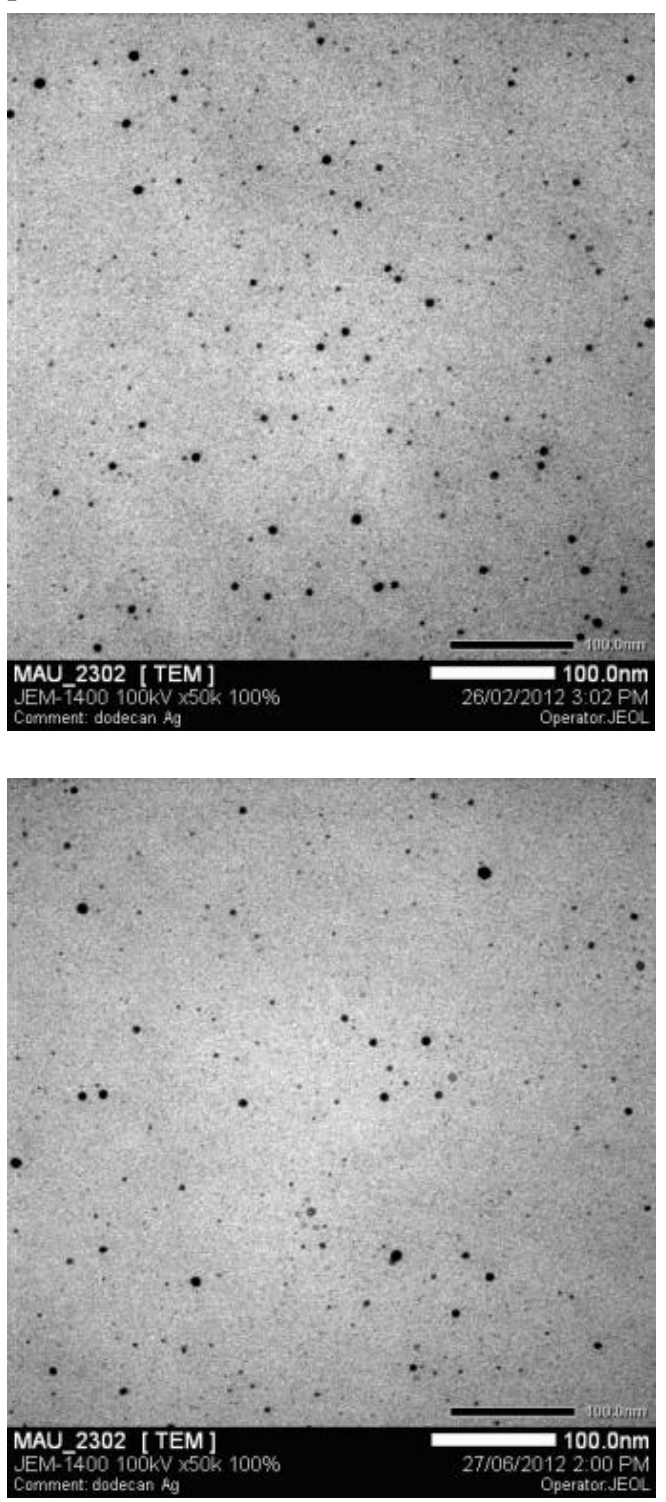

Fig. 7. TEM image of the same colloid synthesized in dodecane before and after 4 months

In fact, there was a research [14] comfirming the absorption of AOT molecules by silver nanoparticles in dodecane by examining the coordination between the sulfonic group and the silver nanocluster. 


\section{Anti-bacterial properties}

Table 3. Anti-bacterial efficiency of the synthesized colloids

\begin{tabular}{|c|c|c|c|c|}
\hline \multirow[b]{2}{*}{ Colloids } & \multirow[b]{2}{*}{ Dilute } & \multirow{2}{*}{$\begin{array}{c}\text { Ag concentration } \\
(\mu \mathrm{g} / \mathrm{ml})\end{array}$} & \multicolumn{2}{|c|}{ After 3-min exposure } \\
\hline & & & $\begin{array}{c}\text { alive bacteria } \\
\text { (CFU/mL) }\end{array}$ & $\begin{array}{c}\text { Biocidal } \\
\text { Effectiveness }\end{array}$ \\
\hline Control & & & $9 \times 10^{7}$ & \\
\hline \multirow{4}{*}{ Ag/cyclohexane } & & 33.69 & $<1$ & $100 \%$ \\
\hline & 2 times & 16.85 & $<1$ & $100 \%$ \\
\hline & 5 times & 6.74 & $<1$ & $100 \%$ \\
\hline & 10 times & 3.37 & $<1$ & $100 \%$ \\
\hline \multirow{4}{*}{ Ag/dodecane } & & 36.26 & $<1$ & $100 \%$ \\
\hline & 2 times & 18.13 & 18 & $100 \%$ \\
\hline & 5 times & 7.25 & 122 & $100 \%$ \\
\hline & 10 times & 3.63 & $1,5 \times 10^{5}$ & $99,83 \%$ \\
\hline \multirow{4}{*}{ Ag/isooctane } & & 49.81 & $<1$ & $100 \%$ \\
\hline & 2 times & 24.91 & 19 & $100 \%$ \\
\hline & 5 times & 9.96 & 192 & $100 \%$ \\
\hline & 10 times & 4.98 & $2,2 \times 10^{5}$ & $99,76 \%$ \\
\hline
\end{tabular}

With very low concentrations of silver nanoparticles (less than $5 \mu \mathrm{g} / \mathrm{ml}$ ) and short time exposure (3 minutes), the colloids could kill almost $100 \%$ of the bacteria.

The excellent anti-bacterial property of the colloids could be explained by the extremely small-sized nanoparticles. The nanoparticles in the range of 5-7 $\mathrm{nm}$ had large surface areas, so the nanoparticles interacted with the bacteria more effectively, inhibiting their growth and reproduction.

Dodecane causes no skin irritation and eye irritation [15], so we can use the colloids in antibacterial products.

\section{Trang 82}




\section{CONCLUSION}

We have successfully synthesized silver nanoparticles dispersed in different solutions. The fabrication process was simple. We did not have to use any other stabilizers after the process. Synthesized nanoparticles were $5-7 \mathrm{~nm}$ in diameter. The colloidal solutions can be stored in normal conditions for several months without agglomeration. With dodecane, the colloid can be used in anti-bacterial application without further treatment. Within the 3-minute exposure to the $E$. coli bacteria, the colloids showed excellent antibacterial properties. Nanoparticles synthesized in cyclohexane, iso-octane are very small and homogeneous, so they can be used in SERS (Surface Enhanced Raman Spectroscopy) application to amplify the signal.

\section{Tổng hợp hạt nano bạc sử dụng phương pháp vi nhũ tương}

- Nguyễn Phước Trung Hòa

- Phạm Thụy Bích Tuyền

- Lâm Quang Vinh

- Lê Văn Hiếu

Trường Đại học Khoa học Tự nhiên, ĐHQG-HCM

\section{TÓM TÁT}

Các hạt nano bạc được tổng hợp từ việc trộn hai hệ vi nhũ tương chứa tiền chất $\left(\mathrm{AgNO}_{3}\right)$ và chất khử $\left(\mathrm{NaBH}_{4}\right)$. Trong hệ vi nhũ tương, chất hoạt động bề mặt được sử dụng là dioctyl sodium sulfonsuccinate AOT. Chúng tôi nghiên cứu các tham số về tỷ lệ mol giữa nước và chất hoạt động bề mặt, loại hydrocacbon (dầu). Tî lệ mol giữa nước và chất hoạt động bề mặt được thay đổi từ 2,5 đến 5; 7,5 và 10. Loại dầu được sử dụng là cyclohexane, iso-octane và dodecane. Sản phẩm tạo thành được đánh giá qua phổ tia $X$, phổ UV-vis và ảnh TEM. Kết quả cho thấy các hạt nano bạc tổng hợp được có kích thước trong khoảng 5 - 7nm, dạng hình cầu đồng nhất. Hệ keo bạc được tạo thành được ứng dụng để diệt khuẩn. Hiệu suất kháng khuẩn của hệ keo bạc rất tốt, trên 99\% với nồng độ hạt bạc khoảng $4 \mu \mathrm{g} / \mathrm{ml}$.

Từ khóa: vi nhũ tương, hạt nano bạc, hình dáng đồng nhất.

\section{REFERENCES}

[1]. C.P. Wong, K.S. Moon, Y. Li, Nano-BioElectronic, Photonic and MEMS Packaging, Chapter 2, Nano-conductive Adhesives for Nano-electronics Interconnection, Springer: New York (2010).
[2]. K. Balantrapu, D.V. Goia, Silver nanoparticles for printable electronics and biological applications, Journal of Materials Research, 24, 2828-2836 (2009). 
[3]. Y. Watanabe, G. Namikawa, T. Onuki, K. Nishio, T. Tsuchiya, Appl. Phys. Lett. 78, 2125-2127 (2001).

[4]. Y. Shiraishi, N. Toshima, Colloidal silver catalysts for oxidation of ethylene, J.Mol. Catal. A: Chem. 141, 187-192 (1999).

[5]. S.Y. Yeo, H.J. Lee, S.H. Jeong, Preparationof nanocompositefibers for permanent antibacterial effect, J. Mater. Sci., 38, 2143-2147 (2003).

[6]. H. Otsuka, Y. Nagasaki, K. Kataoka, PEGylated nanoparticles for biological and pharmaceutical applications, Adv. Drug Delivery Rev., 55, 403 (2003).

[7]. Z. Zhang, B. Zhao, L. Hu, Journal of Solid State Chemistry 121, 105-110 (1996).

[8]. X. Guang-nian, Q. Xue-liang, Q. Xiao-lin, C. Jian-guo, Colloids and Surfaces A, Physicochem. Eng. Aspects 320, 222-226 (2008).

[9]. T. Tsujia, K. Iryob, N. Watanabeb, M. Tsujia, Preparation of silver nanoparticles by laser ablation in solution: influence of laser wavelength on particle size, Applied Surface Science, 202, 80-85 (2002).
[10]. D.V. Phú, B.D. Du, N. Triệu, V.T.K. Lăng, N.Q. Hiển, B.D. Cam, Chế tạo keo bạc nano bằng phương pháp chiếu xạ, Tạp chí Khoa hoc và Công nghẹ , 46, 81-86 (2008).

[11].W. Zhanga, X. Qiao, J. Chen, Synthesis of silver nanoparticles-Effects of concerned parameters in water/oil microemulsion, Materials Science and Engineering B, 142, 1-15 (2007).

[12]. S.J. Oldenburg, Silver Nanoparticles: Properties and Applications, Sigma-Aldrich Reports (2012).

[13]. C.A. Schneider, W.S. Rasband, K.W. Eliceiri, NIH Image to ImageJ: 25 years of image analysis, Nature Methods, 9, 671-675 (2012).

[14]. W. Zhang, X. Qiao, J. Chen, Synthesis and characterization of silver nanoparticles in AOT microemulsion system, Chemical Physics, 330, 495-500 (2006).

[15]. C. Phillips, Materials Safety Datasheet: isooctane, cyclohexane, dodecane, MSDS Number: 100000068314, MSDS Number: 100000014121, MSDS Number: 100000068259 (2012). 